\title{
On Allotopia: The Spatial \\ Accumulation of Difference in Bixiga (São Paulo, Brazil)
}

\section{Jeroen Stevens' and Bruno De Meulder'}

\begin{abstract}
This article will unfold a longe durée spatial biography of the urban area of Bixiga (São Paulo, Brazil) to probe the particular role of space in the conflation of different cultural practices and territorial claims. The extended case study bridges indigenous, colonial, and postcolonial urbanization as they amalgamated an intricate assemblage of material and cultural strata. Combined historical urban analysis and fieldwork allow to uncover how the resulting urban milieu integrates discrepant urban worlds, perpetually iterating between centrality and marginality, innovation and degradation, oppression and resistance. Building on Foucault's (1984) conception of heterotopia, Bixiga will surface as an allotopia, a place that accommodates, cumulates, and celebrates a multitude of differences. It sheds light, this way, on more insurgent histories of urbanism, where urban space is piecemeal forged through contentious struggles over space in the city.
\end{abstract}

\section{Keywords}

Quilombo, central-periphery, cortiço, heterotopia, camp

\section{Insurgent Urbanism Histories}

Holston (1998) introduced the notion of insurgent urbanism in Sandercock's edited compilation "making the invisible visible" to denote the urbanization that resulted from the squatted peripheries of São Paulo and Brasilia. For Roy (2011), Holston made thereby an explicit epistemological shift to decentre urban analysis toward the periphery as an urban praxis and theory in the making. After extensive postcolonial and feminist critique, mostly deriving from social sciences, discourses and practices of urbanism became indeed increasingly challenged with fundamental questions related to by whom and for whom the city is made. By compiling an anthology of socalled insurgent, alternative narratives of urban planning history related to indigenous, popular, and subaltern instances of city making, Sandercock (1998) provoked prevailing paradigms of urban planning.

With empirical insights drawn from Bixiga's urban development, located in central São Paulo, this account seeks to explore insurgent place-making as a crucial for urbanism to engage with the construction of cosmopolitan and inclusive cities. It probes the spatial articulation of social and cultural urban struggles, focusing on how such struggles play out in space, that is, how they

\footnotetext{
'Katholieke Universiteit Leuven, Leuven, Belgium
} 
perpetually take part in the construction, destruction, and reconstruction of the urban environment, while equally taking into consideration how on their turn these social struggles are enabled, invigorated, or constraint by peculiar spatial features of the urban milieu.

The case study and theoretical argumentation will be simultaneously unfolded in three chronological parts. First, specific precolonial traits of São Paulo will introduce entangled narratives of oppression and resistance. The second part will deal with the particularity of Bixiga's territory during the colonial period as it mutated from a "clandestine" hétérotopie de crise, into an hétérotopie de deviation, occupied by an African slave refugee camp or Quilombo. The extensive exchange between the colonial city and the Quilombo will question fundamental issues of centrality and marginality, and illustrate Bixiga's ambivalent character as a central periphery. Third, the arrival of Italian migrants at the end of the 19th century will illustrate how the juxtaposition of urban morphologies and semiotic codes engendered a double morphological neighborhood as both a grid and a labyrinth, and a plural cultural significance as Afro-Italian-Brazilian. Finally, the notion of allotopia will be introduced to designate the particular accumulation of difference that emanates from Bixiga's assemblage of divergent cultural and material urban strata.

\section{Indigenous Urbanisms}

Over five centuries of urbanization, São Paulo's urban fabric engulfed the heavily forested Piratininga plateau, beyond the coastal mountains of the Serra do Mar. For many more centuries, the area that is now South America's largest metropolis was part the Atlantic Forest that covered about $1.500 .000 \mathrm{~km}^{2}$ along the continent's Eastern coastline, permeated by outstretched waterways meandering amid steep hilltops. Long before the first Portuguese disembarked here in the 16th century, nomadic Tupinakins occupied the land in dispersed aldeias, villages of a few large communal houses around a central square. Their subsistence was largely drawn from farming, and consequently sites were changed every few years when the soils reached exhaustion (Morse, 1958). They significantly modified this way natural forest compositions, carrying out large earthworks and laying out roads and fields between countless settlements. Denevan (1992) convincingly dispelled the prevailing "pristine myth" of the allegedly "virginal" precolonial Americas, illustrating how indeed vast indigenous populations largely cultivated the Brazilian East coast long before European traders entered the scene. Nevertheless, there seems to exist broad consensus among anthropologists and archaeologists that the area never knew such highly complex indigenous cities as present day Peru, Mexico, or Colombia, such as the ones described in Low's (2003) often cited indigenous history of the Plaza and deVentós' (1991) Hispanic Labyrinth. Rather, the Eastern area of the continent was supposedly occupied by scattered nomadic tribes that, according to colonial literature, lived in perpetual hostility, waging a merciless "religion of war" against one another (E. V. De Castro, 2011).

The Tupinakins of São Vicente were the southernmost of the Tupinambá tribes that occupied the Brazilian coast as far north as the Amazon River, all speaking a Tupí-Guarani dialect. Métraux (1948), a Swiss pupil of Marcel Mauss, documented their settlements during the first half of the 20th century.

Thirty families, that is, more than 100 people, could live in a dwelling; some houses even had as many as 200 occupants. Houses were constructed on a rectangular ground plan. The roof was arched or vaulted, apparently descending to the ground, thus also forming the side walls $[\ldots]$. The structure was thatched with leaves of pindo palm, patiaba, or capara artfully sewn or woven together so as to be entirely waterproof. There was a low door at each end and one or sometimes two on the side. [ ... ] The centre of the hut was left free as a communal passage-way. The head of the extended family, his relatives, and slaves were accommodated in the middle or in some other privileged part of the long house. Hammocks, carved benches, and pottery of all sizes and shapes comprised the usual household equipment. Villages were located on hilltops [ ... ] defended with pitfalls and caltrops. (p. 103) 
From the 16th century onward, mingle and trade with the first sporadic European settlers was intense in the area. The Tupí communities were particularly anthropophagic, and the absorption of the Other (the stranger, the outsider) meant a prime individual and communal enrichment. For the Tupinakons,

the socius was constructed through relationship with the other, in which the incorporation of the other required an exit from oneself - the exterior was constantly engaged in a process of interiorization, and the interior was nothing but movement towards the outside. (E. V. De Castro, 2011, p. 46)

Indigenous names were conjunctions of those one had cannibalized, and likewise identity and status were advanced through the cannibalistic incorporation of the Other. Supposedly, their involvement with the newly arriving Europeans was, hence, primarily regarded as an enriching asset (E. V. De Castro, 2011).

With the riches of Asia available to them, the Portuguese had little interest in the immediate development of Brazil beyond an imperium for tropical products such as Brazil Wood trees. Usually cut by local Indian groups in exchange for Western products, the Portuguese shipped trees to Europe without a permanent settlement in the tropics (Klein \& Luna, 2010). It were castaway and other "marginal" Portuguese traders that started settling with Tupí-Guarani communities along the coast, after Portuguese captains had dropped off Portuguese criminal exiles in 1500 to acquaint the local language and customs, necessary to put up durable trade connections (Metcalf, 2005). They readily adopted indigenous ways, largely immersing themselves in the indigenous social and cultural world (Morse, 1958). It were those "go-betweens" that eventually became the crucial brokers between the indigenous and Portuguese worlds at the outset of the 16th century (Metcalf, 2005).

\section{Colonial Precursors of an Allotopia}

After three decades of sporadic Portuguese trade expeditions to coastal Brazil, Martim Afonso de Souza established the first permanent Portuguese colony in 1532 at São Vicente, on the Eastern coast of the South American continent. The settlement was strategically located, combining the proximity of fertile grounds on the coastal plain, a benign (micro-) semitropical climate, good open grazing lands, high defensible grounds, and rivers that penetrated deep into the back lands. Until far in the 18th century, the Tupinakin population far outnumbered the Portuguese, isolated from others in the colony to such an extent that probably few of them were not, in effect, Mestizos (Morse, 1958). Most of the Portuguese arrivals came from dubious walks of life that had tempered them for this new hardship and adventure. Early colonial São Vicente was highly informal and resident to a distinctive and unusual combination of Indians, Mestizos, and Whites. Although it concentrated intense mingle, trade, and miscegenation, it remained marginal and peripheral in terms of colonial political power and economic significance.

After successive reports of Portuguese arrivals "going native," a Jesuit mission was send to São Vicente to cease the proliferation of "paganism." In 1553, they established a mission on the Piratiniga plateau, later often depicted as the formal foundation of São Paulo, on a hill at the confluence of the Tiete River's smaller tributaries Tamanduateí and Anhangabaú. Indians were attracted to the settlement by its promises of protection, Western handicraft and the word of God (E. V. De Castro, 2011). The Jesuits, no less than their predecessors, showed great adaptiveness, seeking to transform São Paulo into a communal Christian society by persuasion and compassion rather than by defiance and ferocity. Their anthropophagic culture made the Tupinakins of São Vicente, according to the first Jesuit letters, the ones most open, yet as well the most inconsistent in their conviction to the church. During much of the second half of the 16th century, Portuguese colonists and Jesuit missionaries competed to control, convert, and employ the Tupí-Guarani, striving to convince the Crown that they were best suited to bring them under Portuguese authority (Schwartz, 2010). 
Compared with the Spaniards, the Portuguese were hardly concerned with establishing metropolitan symbols of imperial prestige abroad. The settlement served the Crown rather as a logistical trade outposts similar to the British and Dutch ones of the East India Company, than as an explicit attempt to impose a civic structure. Hence, building codes were almost nonexistent, and the Portuguese colonial town's urban morphology grew rather spontaneously in stark contrast to the rigid grids of the Spanish colonies (Rolnik, 1997). By 1600, São Paulo was a modest and somehow informal town, accommodating about 150 households, White and mameluco, perhaps 1,500 free citizens, and many more Tupinakins in a servile status (Morse, 1958). It remained a small informal trading post, but providing "a unique centre for a dynamic population of explorers and Amerindian slaves" (Luna \& Klein, 2003, p. 12).

Bixiga, the area of study, was situated south of the colonial conurbation, on hilly wetlands covered by dense and tropical Mata Atlântica vegetation. It stretched from the valley of the Saracura River in the West to the valley of the Anhangabaú River in the East. In Tupí-Guarani these names are translated as hiding bird and malefic, referring to the dense forestation of the former and the poisonous waters of the latter. It set the tone for a recurrent depiction of Bixiga as an impenetrable place hidden in the shadow, unhealthy as much as unsafe. As exchange between local Tupí tribes and the world of colonists developed over time, the area increasingly articulated spatial traits of an ambivalent zone of transition or passage between the colonial enclave and the indigenous hinterlands, a spatial disruption of the purportedly hegemonic relationship between colonizer and colonized. As a result, it became the favorable area to dump unwanted but indispensable urban equipments that were considered polluting, discredited, or dangerous (Lanna, 2011). Among others, the gallows, the cemetery of the indigenous and hanged, and the municipal slaughterhouse, were located here (Cirrincione, 2010). Bixiga unfolded as a liminal area betwixt and between the colonial towns' alleged "order" of civilization and control on the one hand; and the tropical forest's assumed "disorder," the crucible of the wild, the savage, and the barbaric on the other hand. In Bixiga, instead, the urban was absorbed in chaotic nature, concurrently corrupted on its turn by the presence of urban elements. By no means Bixiga belonging to either of them, remaining rather an ambivalent term in between antagonistic notions of order/disorder, colonial/indigenous, center/periphery; and consequently considered chaotic, impure, and dangerous by each and all of them. From its very origin, Bixiga was spatially fundamentally different from its environs (Figure 1).

Evidently, the site's population developed a comparable deviant status, not belonging to the colonial city, but neither at home outside of it. Bixiga's toponymy was associated with endemic diseases that frequented São Paulo regularly during the 16th century. Mainly brought in by Europeans, contagion turned epidemic among the indigenous, additionally reinforcing their deviant status. Especially the highly infectious smallpox, pox or red plague, gave bixigas or blisters all over the skin. Some have associated the connotation of the area with the proliferation of these diseases along the Bixiga River, supposedly contaminated by slaughterhouse waste (Marzola, 1979). Others mention a promiscuous hostel named Bixiga, notorious for its lack of hygiene, clandestine practices, and unchristian pastime while generously offering places to those excluded from the city's restricted hotels (Cirrincione, 2010). Whatever be the case, Bixiga appears as an instance of Foucault's hétérotopie de crise, a privileged, sacred, forbidden place, reserved for excluded individuals in a state of crisis vis-à-vis the dominant society: ill, contagious, clandestine. Bixiga emerged as a promiscuous place in the colonial city's shadow, separated, but close enough to shelter its outcast of exiled and diseased for whom the indigenous territory remained likewise alien and inhospitable. All this adds to the characterization of the Bexiguento as the Other, and of Bixiga as a deviant and intriguingly other place of Others.

The susceptibility of the Bixigas, combined with the indigenous' shorter life expectance and growing resistance to enslavement resulted in lower price values for Indian slaves, on the rebound sparking mass importation of African slave labor (Klein \& Luna, 2010). São Paulo's 


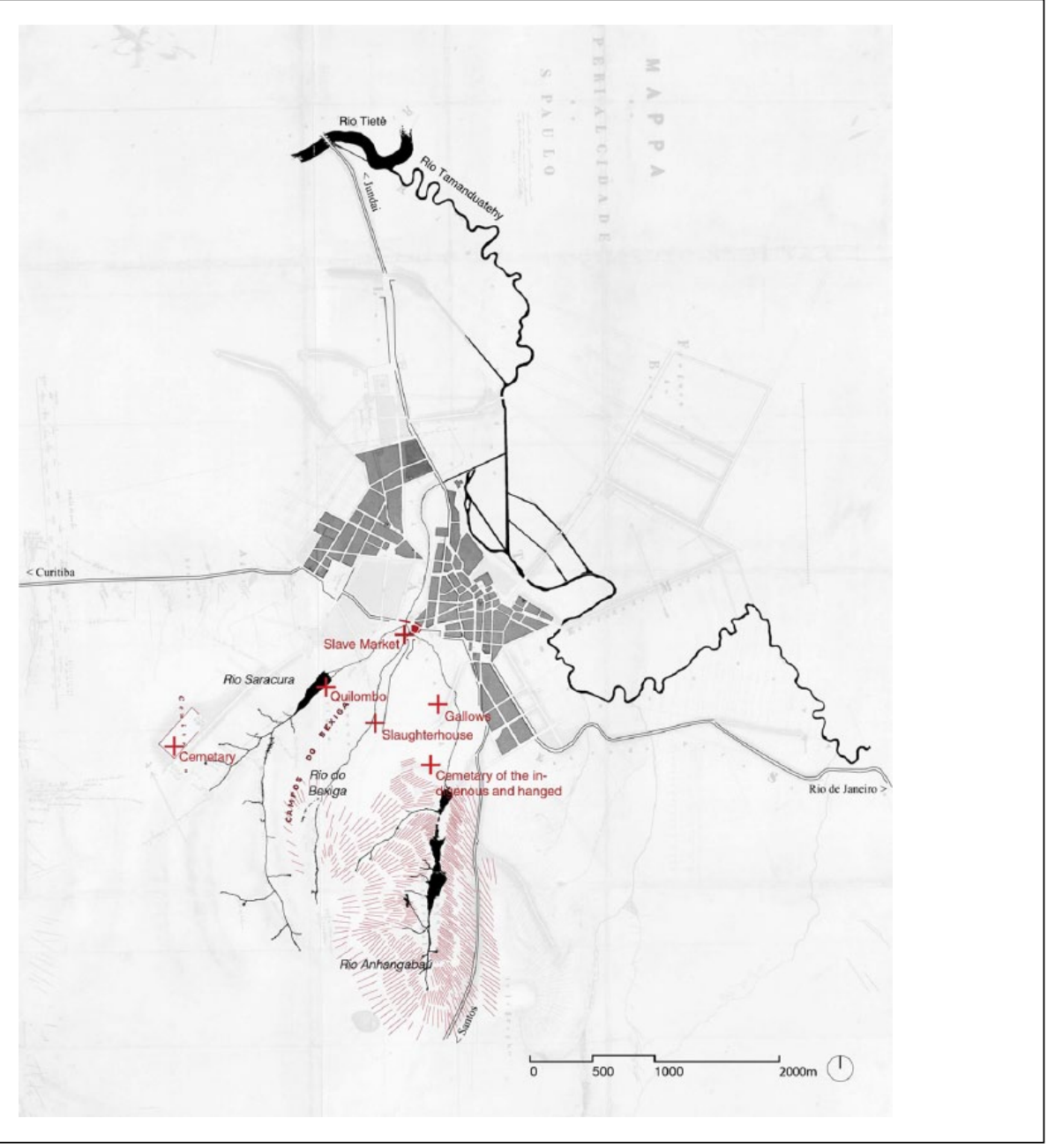

Figure I. Colonial São Paulo in the 17th century with the lands of Bixiga in the Southern periphery. Source. Base map from Secretaria de Estado de Economia e Planejamento, Instituto Geográfico e Cartográfico.

Black population consequently surged over the course of the 18th century, providing the major alternative servile labor that proved to be essential for implementing São Paulo's thriving sugar and later coffee export economy. The Praça de Piques ${ }^{1}$ (Figure 2) was at that moment the most important slave market in São Paulo, and is often designated as the cradle of present day Bixiga. The marketplace was located South, adjacent to the colonial conurbation, strategically located where the main trade route between Santos and the hinterlands transected the city's administrative border. The square, hence, fell outside the strict market governance of the formal city, where authoritarian regulations determined the spatial distribution of commerce. In contrast, Piques was the place of negociações, where the absence of rigid authority allowed for more ambiguous and libertine commercial activities (Lucena, 2013). It served this way not only as the place of arrival for most imported slaves but also as a thriving crossroads between the city's formal and informal realms.

Slaves that managed to escape happened to settle nearby in the Saracura valley, where the steep topography and dense vegetation provided a defensive hiding spot in the city's proximity. They developed the Quilombo Saracura in the vicinity of Bixiga (M. S. De Castro, 2008). The 


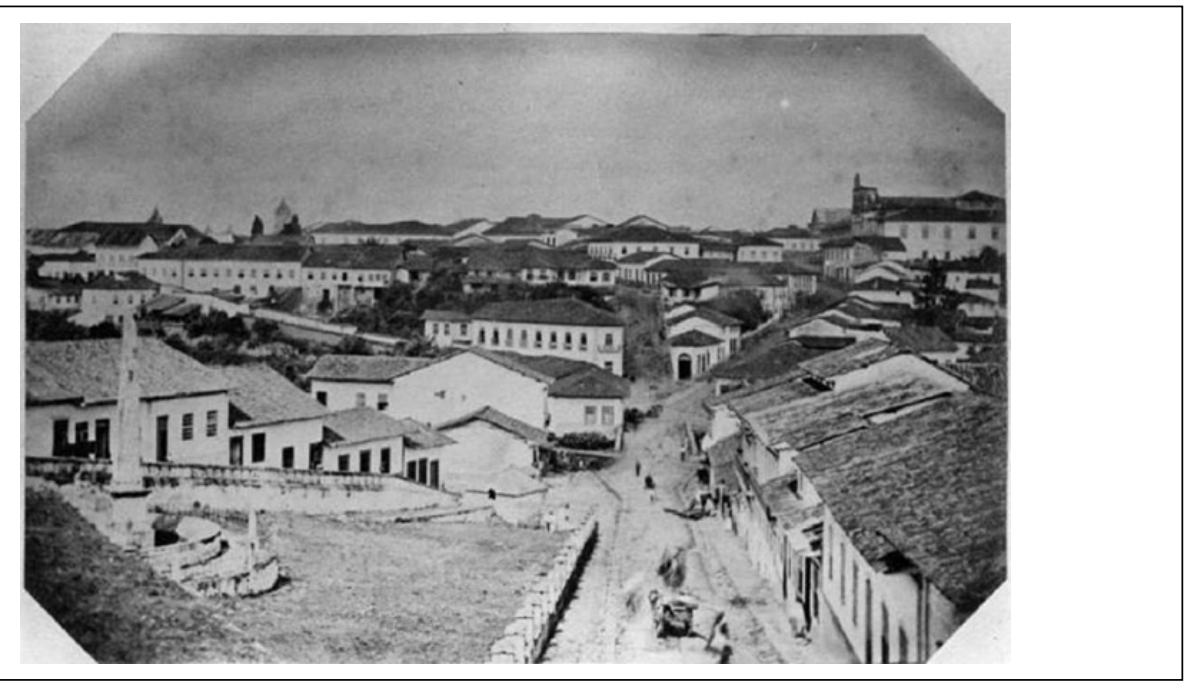

Figure 2. Praça de Piques, the slave market in the vicinity of Bixiga.

Source. Portal de Acervos Artísticos e Culturais da Prefeitura de São Paulo, Casa da Imagem.

etymology of Quilombo, from the Kimbundu Kilombo and the Umbundu Ochilombo, refers to the temporary encampments of nomadic African tribes, but in Brazil it became a popular term for indicating autonomous Black settlements, founded and inhabited by escaped and freed African slaves (Quilombolas) and other minorities of marginalized and socially excluded or oppressed groups. Close by, but also hidden from the city, they constructed houses with clay and tree trunks in clearings in the forest, establishing small parallel societies with their own agricultural production and distinctive cultural praxis (Flory, 1979).

After the importation of millions of Africans, Black slaves accounted for a fourth of São Paulo's total population by the dawn of the 19th century (Andrews, 1991). In addition, the city housed the largest free colored ${ }^{2}$ population of any slave society in the Americas, of which many had become significant slave owners in their own right, largely inscribed in the city's formal economy (Klein \& Luna, 2000). Black São Paulo was consequently not in any way marginal and their subsequent contact with other peoples in the colony produced a remarkably large population of Mestizos, ${ }^{3}$ declaring the city as one of the most peculiar cultural maelstroms of the continent (Schwartz, 2000). The growing colored presence in the city invigorated the spatial ambivalence of the Quilombo of Bixiga. One can easily imagine the ambiguous role the place must have played in the hybrid identity creation of amalgamated Indo-Afro-European populations that extensively roamed between the colonial city, the Quilombo, and the hinterlands. Exchange was particularly intense with, but surely not restricted to the free colored that were living in the colonial city. Various traders collaborated with the runaway slaves, taking advantage of their cheap workforce and products, but the Quilombo attracted free persons of all classes, including White intellectuals, lawyers, and coffee brokers who were deeply involved in the political and commercial life of the colonial city (M. S. De Castro, 2008). The Quilombolas joined the city's informal sector in many ways, largely out of necessity, performing menial or informal services to earn a precarious living, as an early demonstration of the interdependency of formal and informal economy (Machado, 2006). According to Mesquita, Restivo, and D'Ambrosio (2011), Quilombolas' fugitive slave children, known as Negrinhos do Bixiga, maintained wide-ranging relations between the Quilombo Saracura and the city, taking profit of the chaos and congestion at the marketplaces - where it was almost impossible to distinguish slaves, ex-slaves or fugitives - to sell cheap products. 
In addition, also the mysticism of Afro-Brazilian religions as Candomble and Umbanda ${ }^{4}$ exerted great attraction on São Paulo's mixed population. Afro-Brazilian cultural practices flourished in Bixiga's Quilombo, as African refugees were socially and physically closer in their new urban environment as they had ever been before (Prandi, 2000). This way, in the margin of the colonial city, excluded and condemned to precarious survival conditions, the Quilombo developed into a distinctive center of African culture, religion, and music where illicit cultural manifestations as Caiapós,${ }^{5}$ capoeira, drumming, dancing. And swirling Orisha ${ }^{6}$ worship found a stronghold (Rodrigues \& Simson, 2007). Undoubtedly, Bixiga was an espace autre (an other space), a heterotopic space, rendered as abnormal according to the standards of the dominant society. As so often, the hétérotopie de crise mutated into a hétérotopie de déviation, accommodating behavior that was deviant in view of the established and predominant "norm" (Foucault, 1984).

At hindsight, Bixiga, this receptacle for the Quilombolas, appears as an archetypical case for what Remy and Voyé (1981) labelled as an espace à faible légitimité, a second order space where the degree of control is less explicitly determined, consequently allowing for other ways of being to be explored. For Remy and Voyé, the inherent "weak legitimacy" of such a place often propagates oscillating upraises of control and resurgence. In the shadow of the first order city, Bixiga became indeed a contentious and contested territory, as Black rituals were designated by the authority as mental illness, "contributing to insanity and undermining the social order" (Ortiz, 2000, p. 130). Afro-Brazilian cults as capoeira and popular processions and festivities became police targets and were persecuted, turning the Quilombo into an illicit refuge where repression and resurgence were in fact two sides of the same spatial coin.

When Holston (2009, p. 249) argued that "sites of metropolitan innovation often emerge at the very sites of metropolitan degradation", where consequently "the very contition of remoteness in the peripheries enabled an off-work and out-work and out-of-sight freedom to invent new modes of association" (Holston, 2009, p. 257). he actually emphasized how marginality — whether unintentionally - reifies centrality, demonstrating the multifaceted and diffuse power relations that operate between structures defined as "center" (resonating innovation); and spatial structures designated as "margin" or "peripheral" (conventionally associated with degradation and remoteness). The Janus-faced Quilombo, concurrently margin and center allows speaking of Bixiga as a central periphery, integrating fundamental traits of centrality and peripheralness, and cumulating its own centrality as a heart of perpetually contested popular cultures.

As an informal settlement, avant-la-lettre, the Quilombo gradually became a hornet's nest of "mass civil disobedience" (Andrews, 1991, p. 47), where the growing Black population evoked burgeoning conflicts incited by the grinding contradiction between the Christian principles on which Brazilian civilization contended to be based vis-à-vis the harsh reality of coerced labor and hideous slavery practices (Andrews, 1991). In the vicinity of the colonial city, the Quilombo articulated both a struggle for inclusion, claiming equal rights for the Afro-Brazilian population, as well as a struggle for the right to remain different, that is, for the right to deviate from the norm through the practice of illicit cultural practices. Spreading over the province of São Paulo from around the 1770s onward, Black uprisings, rebellion and mass-organized escapes of slaves originating from different Quilombos became increasingly tense after independence in 1822. Also Bixiga's Quilombo made authorities increasingly concerned with the clandestine concentration of rebellious Blacks. In addition, also farmers and organizations depending on slave labor requested more and more measures to halt organized escape and slave resistance (Moura, 1981).

Multiple records document police raids through which Bixiga's ambivalent relationship of parallel belonging and not belonging to the general order is further articulated (Lucena, 2013; Sacchetto, 2001). Frequent raids - ephemeral demonstrations of power-provoked an illusion of control, while their temporary nature simultaneously denied the same. Occasional presence with exaggerated performance of force, impressive means, and warlike equipment perhaps rather 
perpetuated the secondary nature of the place — linked, but clearly also separate from the primary city. While in the center military power was ritualized through the dramatic demonstration of force, order, and power symbols in paradas militar, the periphery requested other means for dramatically affirming power and control (DaMatta, 1984). Is this the equivalent of the colonial army, patrolling in the territory and here and there ruthlessly stepping down in order to "pacify," imposing "legality?" The police action itself-indicating and legitimizing an imposition of the same "legality" as in the "regular" city - is by its occasional and temporal nature, in fact confessing that in "normal" circumstances it remains an area out of their jurisdiction. Regardless of momentary raids, Bixiga goes afterward back to the order of the day. It remains off the map, the foreign universe of Others.

Despite - or encouraged by - proliferating police oppression, Quilombos gained visibility across the country. Supported by the strengthening abolitionist movement in England and the United States, converging forces of resistance eventually enforced the end of slavery on May 13, 1888 (Eakin, 1997). Still and all, exploitation persisted under different forms. The Golden Law in fact implied that "there was no longer any space to speak of slaves, whether as barbarous peoples in need of civilisation or as obstacles in the nation's path" (Machado, 2006, p. 270). Colonial São Paulo's entrenched poverty of rights imbued the city's 20th-century unequal citizenship rights and the Black population would remain stigmatized and excluded in numerous ways up to today (Andrews, 1991). Be that as it may, the celebrations following the passage of the Golden Law took colored São Paulo to the streets of Bixiga in a never foreseen manifestation of pride, proclaiming the first major triumph of a subaltern mass-based movement (Andrews, 1991). The most central street of Bixiga was baptized the Rua 13 de Maio. Today, it is the yearly stage of Black women's parade Ilú Obá de Mim, a ritual public "cleaning" of the symbolic street for broaching the mendacious and "fake" abolition that left and still leaves the city's Blacks oppressed in myriad ways.

\section{Postcolonial Insurgencies}

To compensate the captive labor cut off after 1888 and as a deliberate policy to "bleach" São Paulo's colored population, the Paulistanian elite mobilized European workers. By the turn of the century, Italians were by far the largest group of migrants in São Paulo. Their "liberation" coincided with the massive European exodus that brought some 60 million Europeans overseas (Eakin, 1997). The first wave of Italian migrants, mainly originating from the poor agricultural region of Veneto, arrived in São Paulo during the last decade of the 19th century. Their journey was largely sponsored by the Sociedade Promotora da Imigração (the Society for Promoting Immigration), founded by the Paulista coffee planters to propagandize a wealthy life in the New World's nascent metropolis of São Paulo. In fact, they set up an institutionalized form of human trafficking resonating colonial practices, as arriving Europeans by large ended up in appalling housing and working conditions (Holloway, 1980; Lanna, 2011). Most Italians were housed in the industrializing area between the Tietê River and the brand new railway. Notwithstanding the Italian governmental prohibition of subsidized migration to Brazil, a vast second wave of Italian peasants travelled from the Southern region of Calabria to São Paulo during the first decades of the $20 \mathrm{~h}$ century. They mainly settled in the Planejamento do Bixiga, a large city extension project that was imposed on the marshes of Bixiga. The grid plan, as large as the colonial city itself, was commissioned in 1878 by well-known politician José Antonio Leite Braga. Despite initial plans for erecting a Portuguese charity brotherhood's hospital, speculation replaced civic responsibility and the area was allotted and sold off. The hilly nature of the afforested terrain and regular floods made the land unfit for regular building. Consequently, the allotments - small and narrow-were rather cheap and the erected tenements substandard from the start (Schneck, 2010) (Figure 3). 


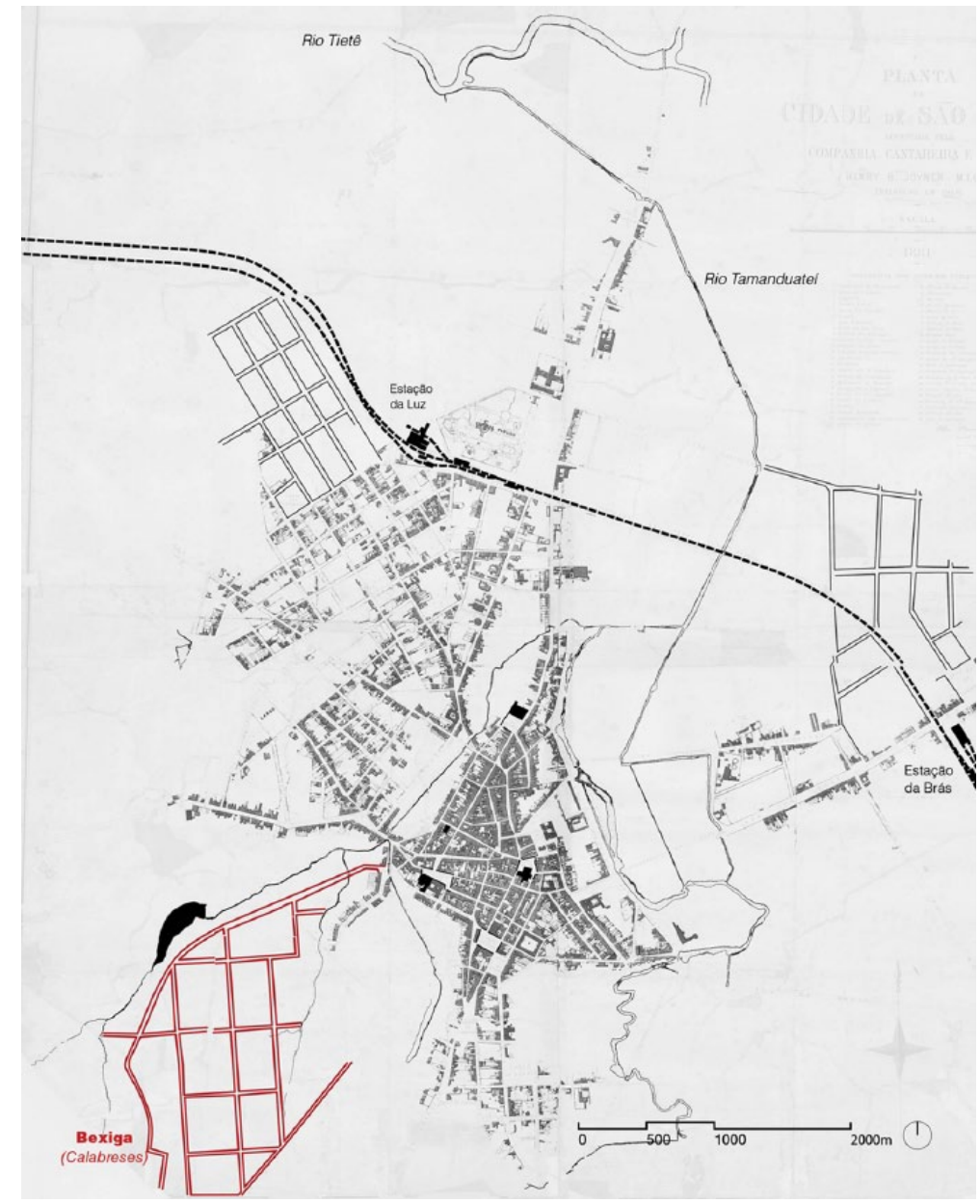

Figure 3. São Paulo in 1890 with the first large extension projects highlighted.

Source. Basemap from Secretaria de Estado de Economia e Planejamento, Instituto Geográfico e Cartográfico.

Residence patterns, the substantial presence of ethnic institutions, house, and land ownership, and local employment indicate the Italians their success in appropriating Bixiga. By 1905, Italian house owners in the neighborhood (officially) outnumbered all other ethnic groups. A variety of dwelling typologies were erected, broadly utilizing construction techniques and architectural concepts of Italian origin (Salmoni \& Debenedetti, 1981). They put up a diversified agglomeration of double floor mansions, with workshop spaces, small factories, bakeries, butcheries, carpentries, shoemakers, and canteens on the ground level, adjacent to the street. The proximity of dwelling, work and leisure spaces attributed a particular cosmopolitan urbanity to Bixiga's streets (Lanna, 2011). The small crafts that the Italian arrivals brought to Bixiga resulted in a multitude of workplaces, predating in fact the large industrial developments yet to come, and in their wake forging a building tissue constructed for simultaneously accommodating dwelling, working, and selling, which made it at the same time flexible for many different uses and users, contributing to the later diversification of the neighborhood given its ability to absorb a plethora of different programs within one and the same spatial framework. 


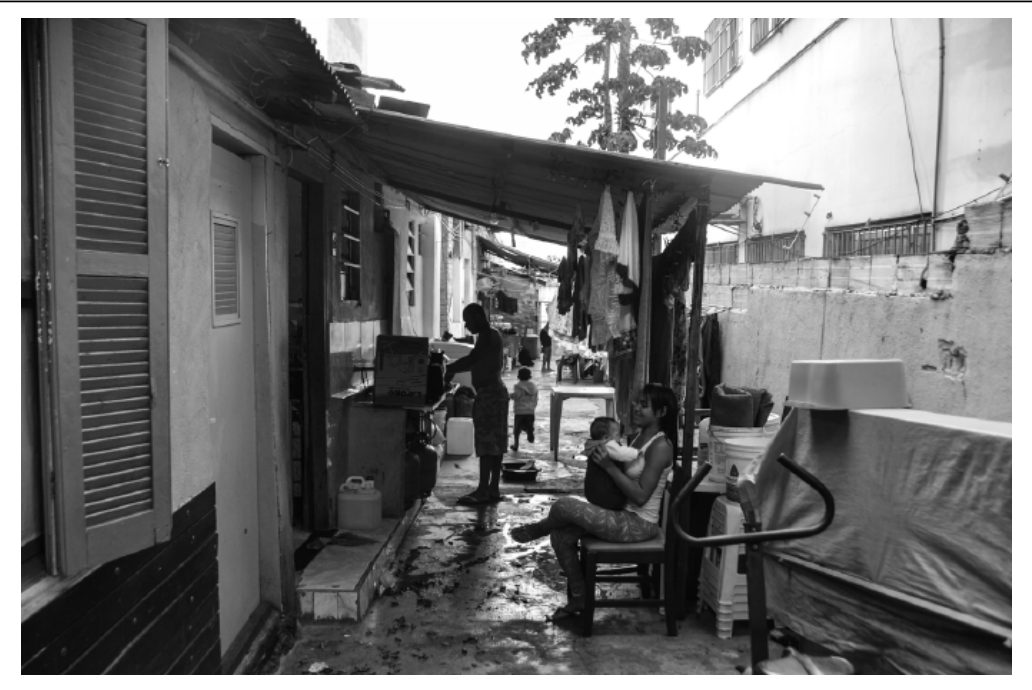

Figure 4. Cortiço in Bixiga, hidden from the street inside of the building block. Source. Photograph by author, 2015.

The over scaled dimensions of the initial grid gave way to large residual spaces inside the building blocks. Moreover, the prevailing narrow Italian shotgun dwelling typology ${ }^{7}$ lend easily to subdivision. Municipal regulations furthermore obliged that sanitary installations should maintain a fixed distance from the dwellings, often resulting in again more underused in between spaces. A variety of residual spaces consequently accrued behind and amid Bixiga's mansions. Almost instantly, these underused spaces were precariously stuffed with inner-city slum settlements, known as cortiços, subrented without governmental control on pricing, density, or construction quality whatsoever (Stevens, De Meulder, \& Sanches, 2019). The cortiços - literally beehives, overcrowded, poorly maintained tenement buildings inside the building blocks - would become the prevailing form of housing for the lowest income class in early 20th-century São Paulo (Kowarick \& Ant, 1989). In the most predictable of Italian stereotypes, a Mafia do Cortiço, managed the business of subletting. Apparently, Bixiga's formal urban development went hand in hand with the instauration of parallel exploitative slum landlord practices. While the street morphology was rigorously ordered and the Italian architecture of the facades particularly fashionable at the time, a labyrinth of slum settlements simultaneously percolated Bixiga's urban fabric, largely inhabited by AfroBrazilian descendants (Figure 4).

Bixiga became notorious for its cortiços, and up to today the neighborhood counts the highest concentration of such inner-city slums in São Paulo (Lopez, França \& Costa, 2010). Their vast presence reaffirmed the connation of Bixiga as São Paulo's squalid skid row. Bixiga's countless cortiços were the reserved liminal spaces of "crime, spaces of anomalous, polluting, and dangerous qualities" (Caldeira, 2000, p. 79). Considered outside the universe of the "proper city," Bixiga was once again stigmatized as a diseased Other place, a festering wound on the face the center. Paradoxically, the neighborhood simultaneously underwent brutal speculation, exploitation, and slum landlordism while at the same time functioning as a reservoir of diverse types of affordable housing. Although close to the center of the city, it was broadly considered a slum. While it was appreciated as artisan neighborhood and popular center of Italian gastronomy, it maintained a controversial reputation as site of occult Afro-Brazilian rituals. Bixiga 


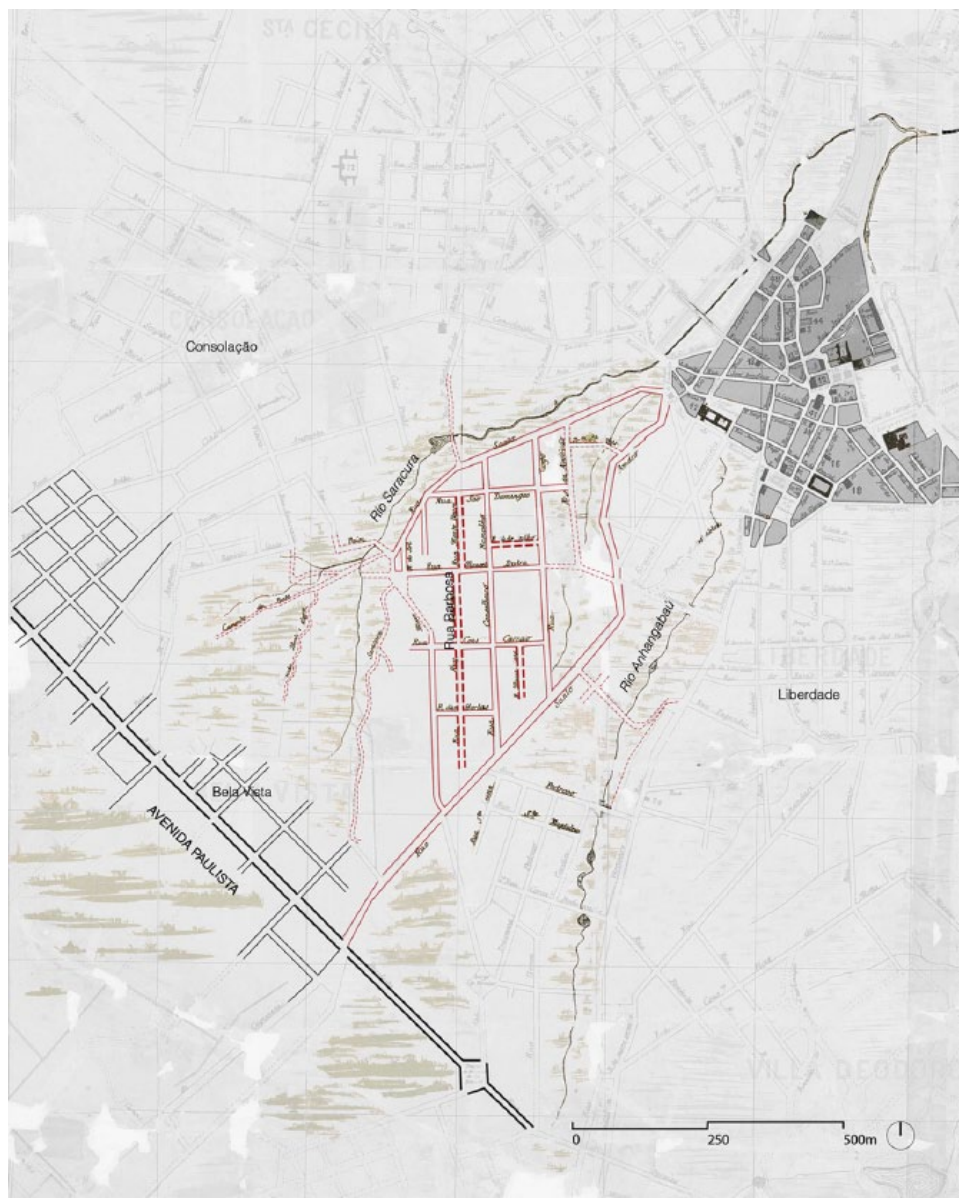

Figure 5. São Paulo in 1897 with Bixiga in-between the new Avenida Paulsita and the historical center. Source. Basemap from Secretaria de Estado de Economia e Planejamento, Instituto Geográfico e Cartográfico.

evolved as a multitude of places where the entangled coexistence of order and disorder, primary and secondary order, formal and informal, extrovert and introvert, exposed and hidden, regulated and organic enable the coexistence of different but mutually dependent social groups. Bixiga became not only a different place but also a place of difference, where seemingly discrepant urban worlds exist side-by-side.

By the dawn of the 19th century, rich coffee farmers settled on the Southern plateau of the Avenida Paulista, wedging Bixiga between the former colonial center and the new central avenue where most economic functions of the city would aggregate. In 1910, the municipality entitled the whole area as the legal district of Bela Vista ("Nice View"), in an attempt to wipe out its pejorative connotation as the cesspit of squalor and smut (Marzola, 1979). Off the map or not, the quarter remained popularly referred to as Bixiga, Bexiga, or Beixiga. Encapsulated between the historic colonial center and the new business center, the site became at the same time twice a periphery (as opposed to the "old" and the "new" urban cores); as well as at least twice a center (of both Italian and Afro-Brazilian culture) (Figure 5). 


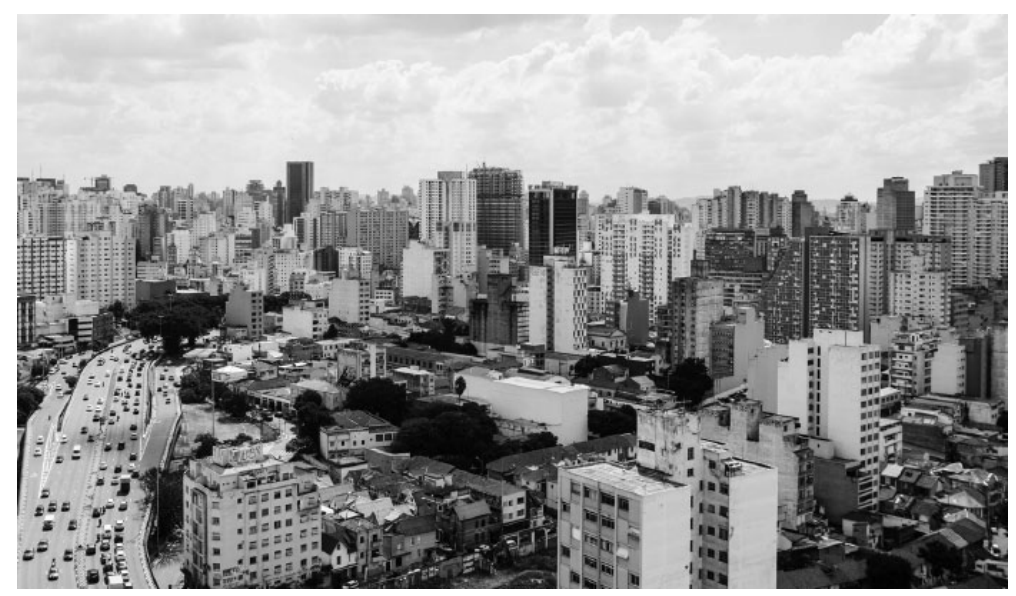

Figure 6. Bixiga as an assemblage of landscape patterns, infrastructures, morphologies, and building typologies.

Source. Photograph by author, 2015.

\section{On Allotopia}

As a palimpsest, Bixiga urbanized through the historical superimposition of both sociocultural and material-spatial strata. The assemblage of material urban fragments sculpted a heterogeneous and polysemic urban environment. Corboz (1983) described the land as a palimpsest, shaped by perpetual processes of human destruction and reconstruction. The metaphor allows to conceptualize how urban form gets shaped by social and cultural "imprints" in the urbanizing environment, subsequently erased and overwritten without however entirely eradicating former inscriptions. The case of Bixiga illustrates how material space, encompassing elements as topography, vegetation, water structures, street morphologies, building typologies, and territorial locations are not merely innocent settings, sculpted by natural and cultural processes, but perform a fundamental agency in their own right in enabling, cumulating, or constraining particular cultures. Successively arriving popular cultures have each been taking part in the gradual construction of a very distinctive urban environment, incessantly piling up semiotic signifiers. The palimpsest here surfaces as a theatrical stage on which social forces arrange an urban scenery, while on its turn the spatial scenery partially but fundamentally steers social and cultural possibilities (Heynen, 2013; Heynen \& Loeckx, 1998). Agencies of social and material culture, hence, play out in space in a particularly intertwined dialogue here.

In Bixiga, the earlier formal/informal duality of the natural and built landscape proved a forceful spatial device for accommodating oxymoronic differences. Seemingly, the mismatch between different spatial structures repeatedly served as a hiding place for the irregular, allowing contradictory urban cultures to coexist in proximity. As Bixiga encompasses both an assemblage of different built structures and of discrepant social realms, the area appears not merely as a heterotopia, the place of the Other (where the Other is the opposite or complement of the "norm"), but rather as an allotopia, a place that insurgently accumulates different, at first sight incongruent, worlds (Figure 6).

This almost mille feuilles-precondition of Bixiga provided the fertile ground for an influential cultural scene to develop in the neighborhood during the 20th century, when the neighborhood 


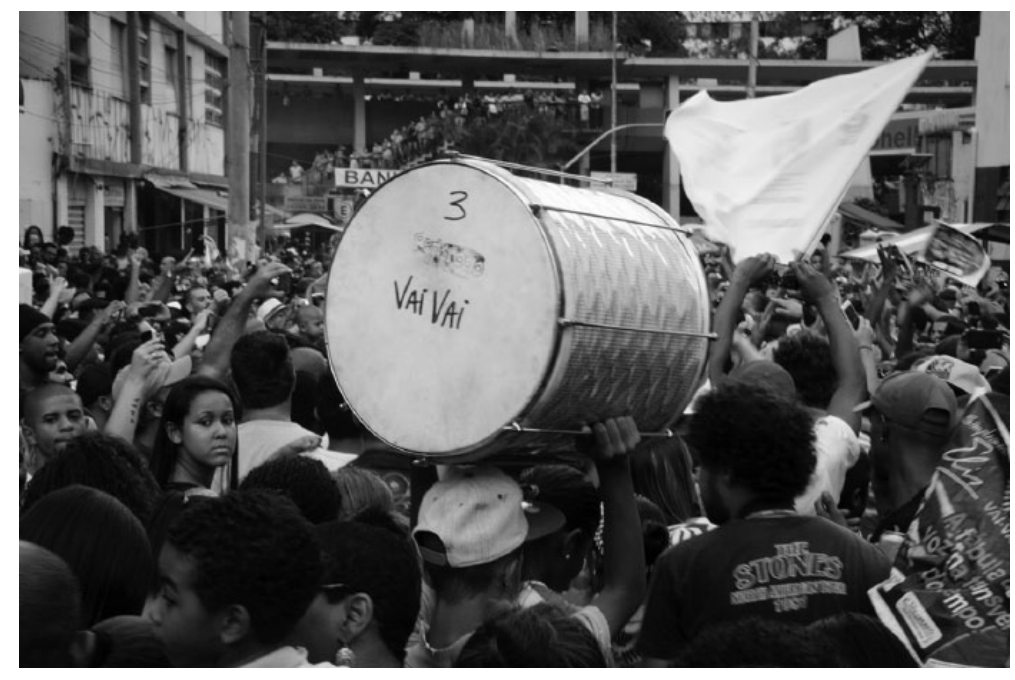

Figure 7. Vai Vai street celebration after its triumph in São Paulo's 2015 carnival concourse. Source. Photograph by author, 2015.

counted the highest population densities within the city (Lucena, 2013). The accumulation of difference unsurprisingly brought in its wake a remarkable concentration of physical and semiotic claims on one and the same territory. At the end of the 1920s, the young Black population regularly met in the neighborhood for salões de raça ("Race Saloons"), specific Black dancing clubs that would later evolve into Bixiga's numerous carnival circles (Rodrigues \& Simson, 2007). From the 1930s onward, the renowned samba school Vai Vai occupied the streets of Bixiga on a weekly basis. Their rehearsals and festivities count as one of the paramount Afro-Brazilian demonstrations in the city. Not coincidently they settled around the former Quilombo Saracura, from where they repeatedly claim space in the city by colorfully as much as invasively demonstrating and manifesting their presence loudly (Figure 7). In Bixiga's central Rua 13 de Maio, the yearly ritualized celebration of the abolition became complemented by Italian festivities and the Catholic procession honoring the Madonna Achiropita (Figure 8). The appropriation of the Black rite resonates the common catholic co-optation of commemorations or important indigenous rituals by relabeling and reconfiguring them for its own purposes. At the end of the 1930s, the first Italian church in Brazil was inaugurated in Bixiga, solidifying the presence of the Italian community while underlining the relative pluralism of the universal Catholic Church in Brazil. Meanwhile, the Black presence in the neighborhood continued to be much higher than generally assumed in official data reports, dominating the streetscape, especially around the Saracura valley (Schneck, 2010).

The proliferation of cultural manifestations indicates a necessity to manifest oneself demonstratively and claim ownership over place. As symbolic representations, they turn Bixiga's public space into a contested arena for negotiating the meaning attributed to the built environment. The plural identity of the built environment instigated daily claims over one and the same urban built environment through ritual processions, demonstrations, and festivals as well as manifestations of popular culture and popular Black festivities, synchronically as well as successively staging a plethora of social scenarios.

In Bixiga, cultural practices claim ownership over a profoundly symbolic urban patrimony, but it remains elusive to what extent these claims are intended as being exclusive or rather 


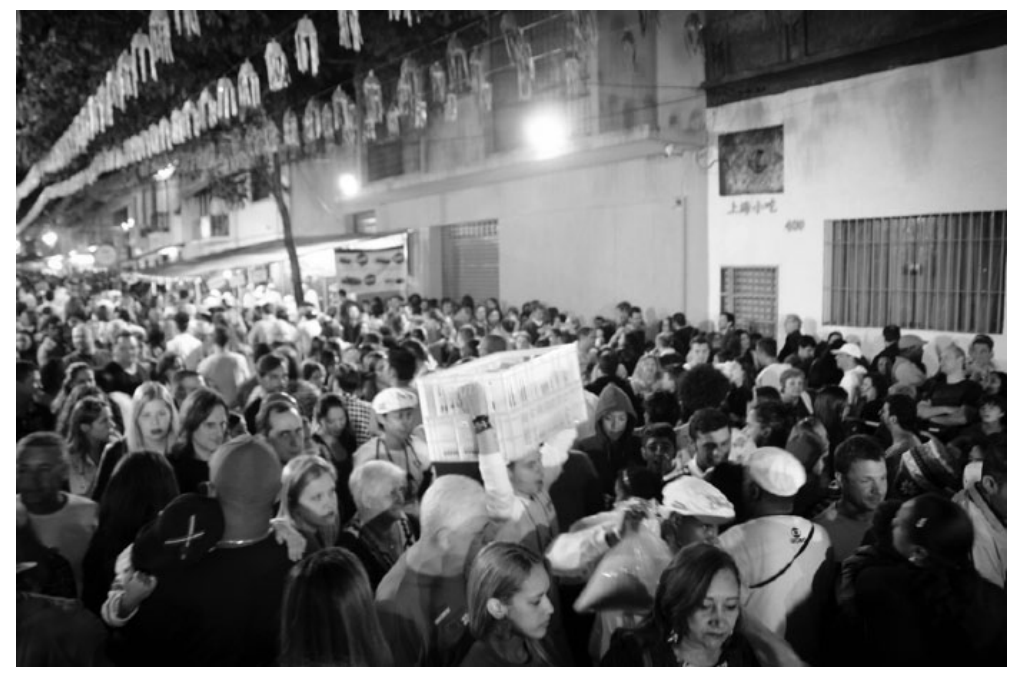

Figure 8. Italian "Achiropita" festival in the Rua I3 de Maio. Source. Photograph by author, 2015.

operate as a form of "time-sharing" the same space, as different performances that successively occupy the same stage, decorating, dressing up, or simply populating specific chunks of the neighborhood. In the resulting urban theatre, each group plays his role, manifesting oneself from time to time in a ritualized or symbolic ceremony to the other, leaving the space for others again afterward. Each in their own right, these cultural manifestations attest a message of belonging to the city, broaching a message of ownership as much to Bixigans as to the rest of São Paulo. At the same time, the multitude of such theatrical occupations keeps the actual cultural "identity" of Bixiga ambivalent and intricately hybrid.

In the 1970s, with the military regime in full-swing, a major East-West highway connection was constructed, cutting through the building fabric of Bixiga for passing the centre (Figure 9). The Elevado Presidente Costa e Silva, popularly referred to as the Minhocão or Big Earthworm is emblematic for the military's authoritarian impact on the city's urban form. Due to its common peripheral and marginal depiction, Bixiga appeared as an obvious location for the technocratic intervention, thereby avoiding the historical center and the Avenida Paulsita. Bixiga was viciously mutilated, cut-up in two pieces, adding another rupture through the multidimensional morphology of the neighborhood. The injured building blocks aggregated vacancy and real estate value around the viaduct nosedived. At the same time, disenfranchised Nordestino migrants from Brazil's impoverished Northern regions arrived en masse in São Paulo in search for job opportunities. While many former Italian families were moving out to richer districts in the city, numerous low-cost bars and lunchrooms, as well as working places were taken over by Nordestino arrivals, broadly stigmatized as an unwelcome and uncivilized outcast (Caldeira, 2000). For a vast urban elite, Bixiga became once more associated with crime and trafficking, gaining a reputation as downtown favela. Periodical police raids - in the best military tradition inherited from a colonial and later authoritarian regime - continued to regularly invade the area in attempts to impose periodical manifestations of "central" authority, the "right," the "legal," seeking to claim control over Bixiga and impose a questionable legitimacy. Also lawmen's performances became part and parcel of Bixiga's daedal urban theatre. 


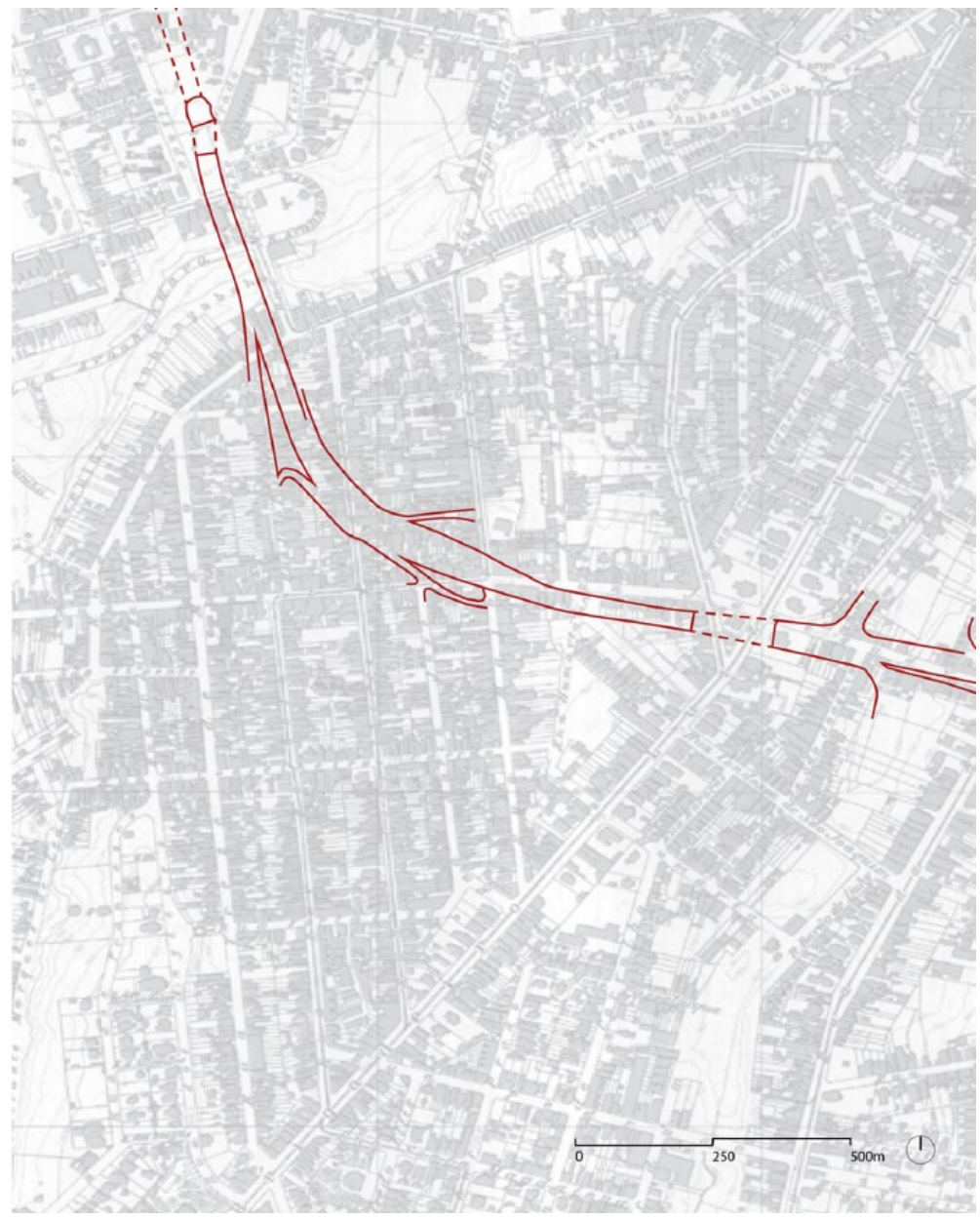

Figure 9. Imposition of the Minhocão on Bixiga's urban tissue in the 1970s.

Source. Basemap from Secretaria de Estado de Economia e Planejamento, Instituto Geográfico e Cartográfico.

From the above, we understand that Bixiga is indeed an espace autre, a peculiar Other space. It presents itself as an allotopia through its accumulation of a multitude of worlds that counterfigure the "regular" and the "norm," allowing mechanisms of exclusion and inclusion to coexist in a unique way. Hence, the notion of allotopia covers difference in at least two semiotic ways, on the one hand as a place that accommodates and accumulates difference, and on the other hand as a place that is in itself different, deviant, and other than the assumed norm. The ideography of Bixiga's urban palimpsest illustrates the semiotic encapsulation of cultural contestation in the city's built environment. Urban space and its spatial relations are on the one hand a cultural product of these struggles, while on the other hand, the uniqueness and spatial transformation of the particular place itself affects the development of specific social and cultural occupations. Bixiga's urban development, hence, demonstrates an entangled development of material and social culture through insurgent processes of appropriation, negotiation, and contestation, contributing all together to the gradual building of a remarkably idiosyncratic and "allotopic" place of difference. 


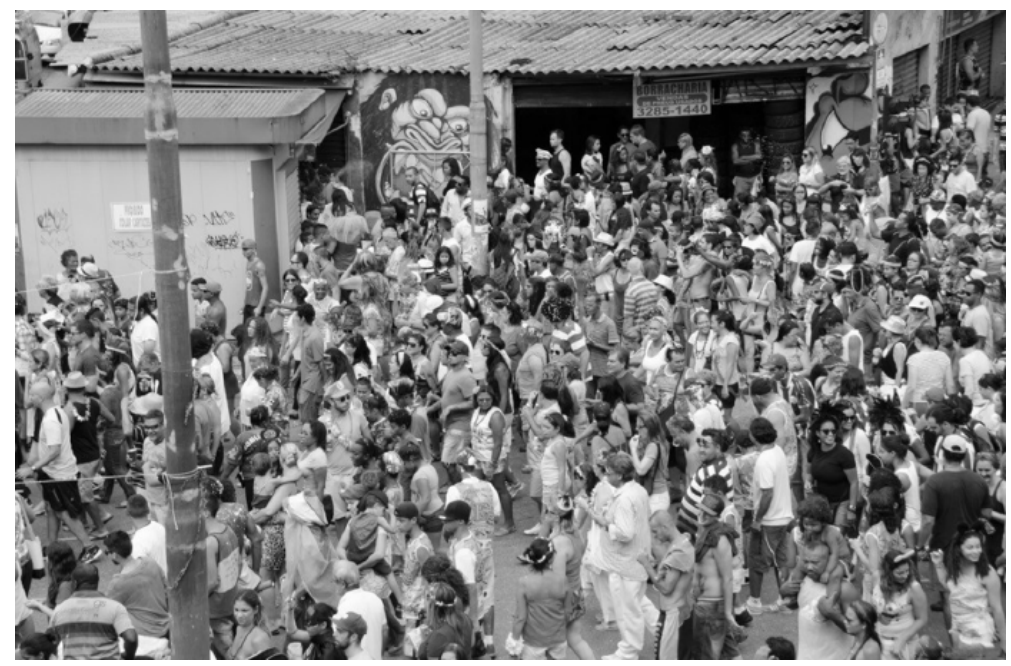

Figure 10. The mixed crowd of Bixiga's Esfarrapado carnival parade. Source. Photograph by Author, 2015.

\section{Declaration of Conflicting Interests}

The author(s) declared no potential conflicts of interest with respect to the research, authorship, and/or publication of this article.

\section{Funding}

The author(s) received no financial support for the research, authorship, and/or publication of this article.

\section{Notes}

1. The present day Praça da Bandeira.

2. The term free colored is used by Luna and Klein (2003) to refer to both persons of color born free (livres) and those who were manumitted (furors or libertos) including pretos (or Blacks) and pardos (or mulattos, or browns).

3. Mestizo is a popular Latin American term for persons of mixed blood.

4. Candomble is an Afro-Brazilian cult originating in Salvador da Bahia, transplanted to Brazil by enslaved Africans. Rituals are based on dance and music, allowing worshippers to become possessed by spiritual protectors or Orishas. The practice of Candomblé is still very active in Brazil and other Latin American countries. Umbanda is an Afro-Brazilian cult that incorporates elements of Roman Catholicism, Spiritism, and Indigenous religions. Originating most probably from Rio de Janeiro, its basic beliefs and practices depart from the use of a medium to get contact with spirits of the spirit of deceased peoples.

5. Caiapós is a cult practiced by the Kayapo indigenous peoples, mainly inhabiting Brazil's plain islands of the Mato Grosso and Pará.

6. An Orisha is a divine spirit, mostly worshiped in cults with African roots.

7. The shotgun house typology refers to the very narrow and deep building figure ground, with the interior spaces organized one behind the other. The metaphor refers to the fact that most of the interior rooms were organized along a narrow hallway thought which one could look through the whole dwelling.

\section{References}

Andrews, G. R. (1991). Blacks and Whites in São Paulo, Brazil: 1888-1988. London, England: University of Wisconsin Press. 
Caldeira, T. P. R. (2000). City of walls: Crime, segregation, and citizenship in São Paulo. Berkeley: University of California Press.

Cirrincione, A. (2010). Brás, Bexiga/Bela Vista, Barra Funda: Estudo antropotoponímico [Brás, Bexiga/ Bela Vista, Barra Fudna: An anthropotoponymic study] (Doctoral dissertation). Universidade de São Paulo, São Paulo, Brazil.

Corboz, A. (1983). The land as palimpsest. Diogenes, 31(121), 12-34.

DaMatta, R. (1984). Carnival in multiple planes. In J. MacAloon (Ed.), Rite, drama, festival, spectacle: Rehearsals toward a theory of cultural performance (pp. 208-240). Philadelphia, PA: Institute for the Study of Human Issues.

De Castro, E. V. (2011). The inconstancy of the Indian soul: The encounter of Catholics and cannibals in 16th century Brazil. Chicago, IL: University of Chicago Press.

De Castro, M. S. (2008). Bexiga: Um Bairro Afro-Italiano [Bexiga: An Afro-Italian neighbourhood]. São Paulo, Brazil: Annablume.

Denevan, W. M. (1992). The pristine myth: The landscape of the Americas in 1492. Annals of the Association of American Geographers, 82, 369-385.

deVentós, X. R. (1991). The Hispanic labyrinth: Tradition and modernity in the colonization of the Americas. London, England: Transaction.

Eakin, M. C. (1997). Brazil: The once and future country. London, England: Macmillan.

Flory, T. (1979). Fugitive slaves and free society: The case of Brazil. The Journal of Negro History, 64(2), 116-130.

Foucault, M. (1984). Des Espace Autres [Other Spaces]. Architecture/Mouvement/Continuité, 5, 46-49.

Heynen, H. (2013). Space as receptor, instrument or stage: Notes on the interaction between spatial and social constellations. International Planning Studies, 18, 342-357.

Heynen, H., \& Loeckx, A. (1998). Scenes of ambivalence: Concluding remarks on architectural patterns of displacement. Journal of Architectural Education, 52, 100-108.

Holloway, T. H. (1980). Immigrants on the land: Coffee and society in Sao Paulo, 1886-1934. Chapel Hill: University of North Carolina press.

Holston, J. (1998). Spaces of insurgent citizenship. In L. Sandercock (Ed.), Making the invisible visible: A multicultural planning history (pp. 37-57). Berkeley: University of California Press.

Holston, J. (2009). Insurgent citizenship in an era of global urban peripheries. City \& Society, 21, 245-276.

Klein, H. S., \& Luna, F. V. (2000). Free colored in a slave society: Sao Paulo and Minais Gerais in the early nineteenth century. Hispanic American Historical Review, 80, 913-941.

Klein, H. S., \& Luna, F. V. (2010). Slavery in Brazil. New York, NY: Cambridge University Press.

Kowarick, L., \& Ant, C. (1989). One hundred years of overcrowding: Slum tenements in the city. In L. Kowarick (Ed.), Social struggles and the city: The case of São Paulo (pp. 60-76). New York, NY: Monthly Review Press.

Lanna, A. L. D. (2011). O Bexiga e os Italianos em São Paulo [Bixiga and the Italian in São Paulo]. In A. L. D. Lanna, F. Peixoto, J. Lira \& M. R. Sampaio (Eds.), São Paulo: Os Estrangeiros e a Construção das Cidades [São Paulo: Foreigners and the construction of the city] (Vol. 1, pp. 117-130). São Paulo, Brazil: Alameda.

Lopez, A., França, E., \& Costa, K. P. (2010). Cortiços: A Experiência de São Paulo. São Paulo: Prefeitura do Município de São Paulo, SEHAB, Superintendência de Habitação Popular.

Low, S. M. (2003). On the plaza: The politics of public space and culture (2nd ed.). Austin: University of Texas press.

Lucena, C. T. (2013). Bixiga revisitado [Bixiga revisited]. São Paulo. Brazil: Istituição Brasileira de Difusão Cultural Ltda.

Luna, F. V., \& Klein, H. S. (2003). Slavery and the economy of São Paulo 1750-1850. Stanford, CA: Stanford University Press.

Machado, M. H. P. T. (2006). From slave rebels to strikebreakers: The Quilombo of Jabaquara and the problem of citizenship in late-nineteenth-century Brazil. Hispanic American Historical Review, 86, 247-274.

Marzola, N. (1979). Bela Vista: Historia dos bairros de São Paulo [Bela Vista: History of São Paulo's neighbourhoods]. Brazil: Secretaria Municipal de Cultura, Departamento do Patrimônio Historico, Divisão do Arquivo Histórico.

Mesquita, M., Restivo, S., \& D’Ambrosio, U. (2011). Asphalt children and city streets: A life, a city and a case study of history, culture, and ethnomathematics in São Paulo. Rotterdam, Netherland: Sense. 
Metcalf, A. C. (2005). Go-betweens and the colonization of Brazil. Austin: University of Texas Press. Métraux, A. (1948). The Tupinamba. In J. H. S. Steward (Ed.), Handbook of South American Indians: The tropical forest tribes (Vol. 3, pp. 95-133). Washington, DC: Smithsonian Institution, Bureau of American Ethnology.

Morse, R. M. (1958). From community to metropolis: A biography of São Paulo, Brazil. Gainesville: University of Florida Press.

Moura, C. (1981). Os Quilombos e a Rebelião Negra [Quilombos and Black rebellion]. São Paulo, Brazil: Brasiliense.

Ortiz, R. (2000). Popular culture, modernity and nation. In V. Schelling (Ed.), Through the Kaleidoscope: The experience of modernity in Latin America (pp. 127-147). London, England: Verso.

Prandi, R. (2000). African Gods in contemporary Brazil: A sociological introduction to Candomblé today. International Sociology, 15, 641-663.

Remy, J., \& Voyé, L. (1981). Ville, ordre et violence: Formes spatiales et transaction sociale [City, order and violence: Spatial forms and social transactions]. Paris, France: Presses Universitaires de France.

Rodrigues, O., \& Simson, M. (2007). Carnaval em branco e negro: Carnaval popular paulistano 1914-1988 [Carnival in white and black: Popular Paulistanian Carnival 1914-1988]. São Paulo, Brazil: Edunicamp.

Rolnik, R. (1997). A cidade e a Lei: Ligislação, politica urbana e territórios na cidade de São Paulo [The city and the law: Legislation, urban politics and territories in the city of São Paulo]. São Paulo, Brazil: Studio Nobel.

Roy, A. (2011). Slumdog cities: Rethinking subaltern urbanism. International Journal of Urban and Regional Research, 35, 223-238.

Sacchetto, J. (2001). Bixiga: Pingos nos is [Bixiga: Straightening things out]. São Paulo, Brazil: Lemos.

Salmoni, A., \& Debenedetti, E. (1981). Italian Architecture in São Paulo. São Paulo, Brazil: Perspectiva.

Sandercock, L. (1998). Making the invisible visible: A multicultural planning history. Berkeley: University of California Press.

Schneck, S. (2010). Formaçao do Bairro do Bexiga em São Paulo: Loteadores, Proprietários, Construtores, Tipologias Edilicias e Usuários [Formation of the neighbourhood of Bexiga in São Paulo: Entrepreneurs, owners, builders, typologies and users] (1881-1913) (Doctorol thesis). Universidade de São Paulo, São Paulo, Brazil.

Schwartz, S. B. (2000). Brazil: Ironies of the colonial past. Hispanic American Historical Review, 80, 681-694.

Schwartz, S. B. (2010). Early Brazil. A documentary collection to 1700. New York, NY: Cambridge University Press.

Stevens, J., De Meulder, B., \& Sanches, D. (2019). Cortiços: Interstitial Urbanization in Central São Paulo. In R. Rocco \& J. Van Ballegooijen (Eds.), The Routledge Handbook on Informal Urbanisation (pp. 248-258). London, England: Routledge.

\section{Author Biographies}

Jeroen Stevens is an architect and an urbanist, currently engaged as researcher at the OSA Research Group on Urbanism and Architecture at the University of Leuven (Belgium). His research deals with the agency of popular movements in performing particular instances of urbanism.

Bruno De Meulder teaches urbanism, urbanism history, and theory and practice at the department of architecture at the University of Leuven (Belgium). He coedits UFO: Explorations of Urbanism (Zurich, Park Books) and publishes regularly on issues of urbanism in the postindustrial and postcolonial era. 